\title{
SUPPLY OF SCIENTISTS AND TECHNOLOGISTS FOR INDUSTRY
}

T THE report on "Industry and Technical Progress"* contains a key chapter on the supply of "Trained Men and Women", and a conference organized by the British Association was held to discuss this subject, under the chairmanship of Sir Henry Tizard, at the University of Leeds on July 5. In welcoming this well-attended Conference on behalf of the University, Prof. J. T. Whetton emphasized that the problem has many roots, some of which go deep into the schools and the social system. The additional recruits required for British industry cannot be produced like rabbits out of the additional hat now being provided by the expansion of facilities in the universities and technical colleges, and Prof. Whetton's concern about solving the equation of supply and facilities became a recurrent preoccupation throughout the day. Mr. R. J. Butler welcomed the Conference on behalf of the Leeds Chamber of Commerce, and asserted that costconsciousness is not an inferior aspect of an engineer's work but a vitai part of it, for which appropriate training should be given both before and after entry to industry.

Six main points were stressed by Prof. B. R Williams (University College of North Staffordshire) in a brief introductory survey of the report, of which he is joint author. First, the use of science by industry is not simply a matter of buying a few scientists and providing a back room; rather it is essential to have the widest spread of scientifically minded people throughout the firm. Secondly, the complex chain of relationships between firms has been shown to have a powerful cumulative effect on productivity, or the lack of it. Linked with both these aspects, and of critical, indeed over-riding, importance is the quality of management. Where management is good, so generally is the use of science and technology in the firm. The total supply of technologists is extremely important, but the case studies have shown the critical lack of 'hybrids', that is, people who have mastered more than one discipline, be it mathematics and chemical engineering, physics and metallurgy, or engineering and economics. Finally, finance is not nearly so serious a problem as the shortage of scientists and technologists and the quality of management. We should know when we had solved this problem when finance once more became the limiting factor.

"Behind all the factors affecting our study stands the question of the supply of able minds-managers, scientists and technologists; and it will be seen that we are satisfied neither with the effectiveness of the British educational system in its work of selection of training, nor with the distribution of trained talent between industries and firms." With this quintessential quotation from the report, Sir Henry Tizard introduced its co-author, Prof. C. F. Carter (Belfast), who stressed two aspects of this question. First was the supply of first-rate ability, which is a question of nurturing what we have: secondly was the lack of

- Industry and Technical Progress: Factors Governing the Spefd of Application of Science. By Prof. C. F. Carter and Prof: B. R. Williams. Pp. vili + 244. (London and New York : Oxford University Press, 1957.) 258. net. (See also p. 301 of this issue of Nature.) training of various kinds, which may be dealt with by official policy. Prof. Carter indicated possible lines of action which the Conference might consider ; for example : that employment advisory services for young people should operate in grammar schools before the crucial age of specialization and not at the time of leaving school ; that allowances, subject to a means test, should be given to children remaining at school after the age of nfteen ; specialized university entrance should be greatly relaxed; that consideration be given to a two-tier system of university degrees in science ; that more research be undertaken into the teaching of mathematics, and into the elimination of much drawing-office work, and by the professional institutions into the efficient use of scientific and technical staff in industry.

With Sir Ben Lockspeiser in the chair, the second morning session began with Sir Alexander Fleck stressing industry's responsibility as a provider of scientists, as well as in receiving them and using them properly afterwards. In both respects, however, he was concerned with wider education conducive to good personal qualities and powers of leadership. There is urgent need to achieve a new balance between science and the arts, and Sir Alexander commended both the courses at the University College of North Staffordshire and the new proposals at Cambridge. Careful examination should be made of the use of scientists in industry, but there is a proper place for them on the sales side, especially on the way to top management, and this is not fairly described as 'edging nearer the till'. In Imperial Chemical Industries, one in four are engaged on research and development; for the other three a high degree of technical efficiency is desirable, but personal qualities vital in teamwork and leadership are at least as important. Education and training must take account of these trends, which are bound to continue, and science could no longer be regarded as an optional extra to traditional subjects. The education of the scientist must prepare him to take a full part in the management of industry.

The worst shortage in the atomic energy industry, that of design engineers, was discussed by Sir Christopher Hinton. There is no general agreement as to the training of engineers, because it is inherently more of an art than a science, and this art can be learnt only by practical experience in industry. For this reason, though some expansion was justified, a large expansion of university engineering schools would be a serious mistake. More should come through the technical college route, with early industrial experience to get the real feel of engineering, and with concurrent or closely related theoretical study. Sir Christopher illustrated this by reference to the design office establishment of the Atomic Energy Authority at Risley. Of 158 professional staff only fifty-three have degrees, and some of these were external degrees taken part-time through the technical colleges. The remainder had come via the part-time day- and evening-class route alongside industrial experience. Of 226 at the assistant designer grade, only seventeen have degrees, but this 226 
forms the main source for supplying the professional grade. There are 286 in the drawing office grades and none has a degree, but they are very good design staff. This was the total establishment which had been responsible for the solution of major engineering problems in the atomic energy developments. Conversely, of ninety experimental officer grades, fortyseven had degrees, but the posts needed only the General Certificate of Education at advanced level in two subjects. Sir Christopher was very concerned about the consequent waste of university places in a period of great shortage. At the same time, he was equally concerned about what industry did to graduates after entering employment. After ten years employment, British graduates too often compare unfavourably with those in United States industry in vigour and initiative.

The wider education and effective training of graduates in industry was then examined by Guy Hunter, deputizing for Sir Reginald Verdon-Smith (Bristol Aeroplane Co., Ltd.). These are essential both for good management of industry and the general well-being of the nation; the latter especially, since such graduates increasingly occupy key positions, and will greatly influence the transmitting of the national tradition of moral, social, political and cultural values, and will also lay the foundation for the much greater weight of technology needed to sustain modern society. Industry should organize two-year postgraduate training as continued education as well as industrial training, preferably on a sandwich basis, with the universities, advanced technical colleges and industry itself supplying the varied advanced teaching required.

'The afternoon session under the chairmanship of P. A. Macrory (Unilever) was devoted to the concern of the schools, colleges and universities with the supply of scientists and technologists. Dr. A. D. I. Nicol (University of Cambridge Appointments Board) was concerned with the unpredictable nature of State scholarship and open scholarship results. For example, of the State scholarship students of mathematics at Cambridge, 70 per cent had obtained only third-class honours degrees. More pass and general honours degree courses might be run for those who aim at technical careers apart from research, but the able scholars should not be sacrificed to these requirements. For them a four-year course or more postgraduate courses are now essential. In the schools a taste for advanced mathematics must be more widely cultivated, since it is the universal language of modern science, and all understanding is limited if some mastery is not attained in it.

As he had first-hand knowledge of it in his local education authority area, A. B. Clegg (chief education officer, West Riding of Yorkshire) was concerned with the problem as to why only 6 per cent of the children of unskilled workers capable of doing sixth-form work actually remain at school, as against 44 per cent of the children coming from professional and managerial classes. He examined the cumulative effects of two main causes, lack of parental ambition and the educational handicaps of the social background of many of the children of unskilled workers, and considered that the role of the school, in offsetting these serious drawbacks, should be to provide a broader education and background to literacy, and to develop wider interests and easy social relationships. But all this is increasingly limited by specialization, rising examination standards, and especially by the impact of the open scholarship system of Oxford and Cambridge. It bears most severely on the socially handicapped able child, in a school likewise handicapped. Unless this difficult matter is dealt with, it may become as highly charged politically as the "elevenplus' test has become since the Second World War, and it may well invite increased government probing into university affairs. With suitable safeguards, some experiments should be made in allowing such schools to nominate their own university entrants, when the error's are unlikely to exceed the 17 per cent or so now typical of local authority awards.

From the angle of technical education, Dr. P. F. R. Venables (Birmingham College of Technology) found some encouraging trends since the White Paper was published. A new structure is emerging, more allied to the needs of industry: local and area colleges concerned with courses for technicians and craftsmen, some eighteen regional colleges (rising possibly to thirty) concerned with advanced courses for the foregoing and a limited number of courses for technologists ; and the eight (probably ten) colleges of advanced technology concerned solely with training scientists and technologists. Part-time day release enrolments have already increased by about 8 per cent, City and Guilds examination results by 13 per' cent ; full-time advanced courses have risen by 9 per cent, and similar part-time day courses by 4 per cent. Sandwich courses had an intake of some 1,200 as compared with an output of about 500 the previous session. Of 173 sandwich courses which have nøw been started, twenty-five have been recognized by the Hives Council for the new diploma in technology (in addition there are six full-time courses so recognized). Qualitative problems noted in the report under discussion are being met by the introduction of industrial administration, economics and related subjects, and of liberal studies, into all undergraduate courses. Nevertheless, there remains serious cause for concern in the wastage of ability in part-time courses, the lack of women students, insufficient training after entry into industry and, above all, the continuing critical shortage of highly qualified teaching staff.

Coming at the end of the various papers and earlier discussion, C. H. Wilson (University of Leicester) tried to put some points in perspective. Too many mutually contradictory arguments had been used; for example, that standards should be raised in the universities, while they should admit many more by lowering faculty requirements and abolishing the scholarship system. There was also a complete lack of reality in piling ever more tasks on to the universities: the quinquennial grants had been fixcd, and therefore their potential work was already limited, and additional suggestions must remain pipe dreams. Mr. Wilson cited as evidence of loss of ability the fact that of those leaving the public schools at seventeen and eighteen years of age, only 44 per cent went on to university and other advanced education, and the figure for maintained grammar schools was 41 per cent. The perseverance for science and mathematics courses was greater, the respective figures being 81 per cent for public schools and 50 per cent for maintained grammar schools. Numbers should be increased without lowering standards, by rescuing the general degree from the neglect into which it has fallen; but industry must first make up its mind as to what proportion of specialists (honours degree men) it wants in comparison to those whose future occupations require a good general science training. 
The task of summing up the contributions of thirteon speakers and twenty-four participants in the discussion was allotted to Sir Henry Tizard, but he wisely preferred to round off the conference by stressing only a few salient points. If the supply of scientists and technologists who will remain as such is doubled, it will probably be adequate; but a very much greater increase is required in the number of scientifically educated people for industry, and indeed all walks of life. Specialization has no evils for the able man, and the university and advanced college are appropriate places for this specialization. Not so for the remainder, and greater care must be taken to secure a wider education for them. Everyone agrees that the British educational system is not meeting modern needs, but there has been substantial progress in the schools, colleges and universities. In his day at Westminster School, Sir Henry said that only one other boy was studying science; now the yearly increase is 10 per cent and the science sixth will soon equal the rest. 'lechnical education is progressing rapidly in quality and quantity, and should be given far more money for its needs. A comparative survey of the systems of all the western European countries is urgently needed. Though universities are complaining, Sir Henry said that he knew of no other European government which makes a recurrent grant equal to £31 million per annum to universities. How do those universities manage? And what light would such a survey throw on British university organization? Far more trust is needed between the universities and the schools in Britain, and one of the younger universities should take the initiative in making closer direct examination and nomination arrangements with selected schools. A pilot experiment, conducted some years ago at the Imperial College of Science and Technology, London, had improved relationships and the number of first-class people coming forward.

Well organized as the conference was, it had too crowded an agenda, with an almost breathless succossion of speakers and participants. An opportunity was lost in not spreading the same programme over two days, with far more ample opportunity for discussion, and particularly for members to question the authors more closely upon many aspects of their valuable report.

\section{P. F. R. Venables}

\section{CAPITAL FOR SCIENTIFIC DEVELOPMENT}

\begin{abstract}
$\mathrm{T}$ HE conference on "Capital for Scientific Development" at the Royal Society of Arts on June 27 was the earlier of two conferences arising out of the inquiry conducted by the Science and Industry Committee of the Royal Society of Arts, the British Association and the Nuffield Foundation into the possibility of speeding up the application to industry of the results of scientific research. The other conference, on the supply of scientists and technologists for industry, is surveyed in the preceding article. In opening the conference the President of the Board of Trade, Sir David Eccles, suggested that the weakness of British industry lies in failure to pay enough attention to the cost of applying new processes and machines, and that the value of Profs. Carter and Williams's book lies in stimulating thought about industry and technical change, and in challenging generalizations too broad to be true. Sir David agreed that company taxation might be less of a deterrent than some people think, but said that it mattered what they thought and that the answer depends on whether, assuming any rate of taxation, the public sector would leave the private sector enough savings.

The subject was dealt with in two sessions devoted respectively to large and small firms, but the discussion was preceded by a short account of the survey by Prof. C. F. Carter, who summarized its findings on this point. At the time of the survey many firms were certainly not held back by lack of finance, although they might be described as stagnant pools. Others, including some highly progressive from a technical point of view, had their development limited by the difficulty of retaining enough money in a period of high taxation, or by their inability or unwillingness to raise money from outside. Prof. Carter suggested that the problem, in its broadest terms, was whether the supply of savings was as high as it could reasonably be made, and whether our financial machinery was such that these savings were available to the investment borrowers with the
\end{abstract}

best claim. These questions raised very wide issues, some of which, including the place of the National Research Development Corporation in the financial support of key developments, Prof. Carter indicated.

The discussion on the position of the large firm was opened by Lord Dudley Gordon, who thought that new capital was normally required to develop the results of research in an existing department, and he found it hard to accept the suggestion in the report that a board of directors might refrain from increasing a dividend so that it may have funds to erect a new factory. Lord Dudley observed that surpluses shown are not usually available as cash, and new development resulting from research has to be paid for in cash. Large sums have also to be found for main. tenance and repairs and to comply with the provisions of such measures as the Clean Air Act, and nearly every major project involves raising additional capital in some form, rather than cash from internal resources.

Sir Nutcombe Hume, who opened the discussion on the smaller firm, said that the conclusions drawn by Profs. Carter and Williams on capital for development accorded with those reached by the Charterhouse group of companies, of which Sir Nutcombe Hume is chairman, as a result of their experience in this field. Sir Nutcombe thought there were all too many men in responsible managerial positions, especially in the smaller companies, who did not know the extent of the facilities available and their uses. An essential ingredient of good management was the realization that, at least in matters of finance, a company must choose some reputable finance house and trust it to do what is best for the company. He also pointed out that the mininum size for a company to prove attractive to the Stock Exchange and investors seeking a free market in the securities they hold had been growing for many years, and he did not think that the report distinguished strongly enough between capital in the 